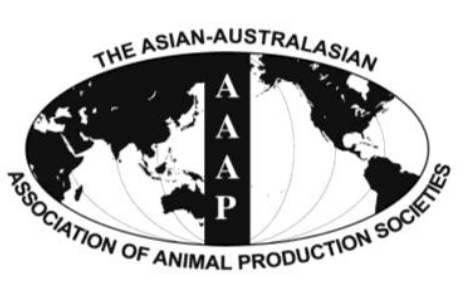

Open Access

Asian Australas. J. Anim. Sci.

Vol. 28, No. 1 : 79-85 January 2015

http://dx.doi.org/10.5713/ajas.14.0313

pISSN 1011-2367 elSSN 1976-5517

\title{
Antioxidant Enzyme Activity and Meat Quality of Meat Type Ducks Fed with Dried Oregano (Origanum vulgare L.) Powder
}

\author{
J. H. Park, S. N. Kang ${ }^{1}$, D. Shin ${ }^{2}$, and K. S. Shim ${ }^{3, *}$ \\ Department of Animal Resource and Science, Dankook University, Cheonan 330-714, Korea
}

\begin{abstract}
One-day-old Cherry valley meat-strain ducks were used to investigate the effect of supplemental dried oregano powder (DOP) in feed on the productivity, antioxidant enzyme activity, and breast meat quality. One hundred sixty five ducks were assigned to 5 dietary treatments for 42 days. The dietary treatment groups were control group (CON; no antibiotic, no DOP), antibiotic group (ANT; $\mathrm{CON}+0.1 \%$ Patrol), $0.1 \%$ DOP (CON+0.1\% DOP), $0.5 \%$ DOP (CON+0.5\% DOP), and $1.0 \%$ DOP (CON+1.0\% DOP). Upon feeding, 1,1-diphenyl-2-picryl-hydrazyl (DPPH) radical scavenging activity of oregano extracts was higher than that of tocopherol, although it was less than that of ascorbic acid. As a result of in vivo study, DOP in the diet showed no effects on final body weight, feed intake, or feed conversion ratio. However, dietary $0.5 \%$ and $1 \%$ DOP supplementation caused a significant increase in the serum enzyme activity of superoxide dismutase (SOD) compared with CON and ANT, while glutathione peroxidase (GPx) in tissue was increased as compared to ANT ( $<0.05)$. Cooking loss from ducks fed with DOP decreased compared with the control ducks. Thiobarbituric acid reactive substance (TBARS) values of duck breast meat at $5 \mathrm{~d}$ post slaughter was found to be significantly reduced in ducks whose diets were supplemented with $0.5 \%$ and $1 \%$ DOP $(\mathrm{p}<0.05$ ). These results suggest that diets containing $0.5 \%$ and $1 \%$ DOP may beneficially affect antioxidant enzyme activity of GPx and SOD, improve meat cooking loss, and reduce TBARS values in breast meat at $5 \mathrm{~d}$ of storage in ducks. (Key Words: Antioxidant Enzyme Activity, Duck, Meat Quality, Oregano, Phenolic Compound)
\end{abstract}

\section{INTRODUCTION}

In recent years, there has been a growing interest in isolating antioxidants from plant ingredients and using them in animal nutrition with the intention of replacing antibiotics. Many studies have been exploring the additive effects of herb materials such as oregano, rosemary, thyme, sage, basil, and mint as growth promoters, antimicrobial agents, or natural antioxidants in poultry production (Botsoglou et al., 2003; Guo et al., 2004; Hernandez et al., 2004). And these plant extracts have shown potential as

\footnotetext{
* Corresponding Author: K. S. Shim. Tel: +82-63-270-2609, Fax: +82-63-270-2614, E-mail: ksshim@jbnu.ac.kr

${ }^{1}$ Department of Animal Resources, Daegu University, Gyeongsan 712-714, Korea.

2 Department of Food and Nutrition, Hallym University, Chunchoen 200-702, Korea.

3 Department of Animal Biotechnology, Chonbuk National University, Jeonju 561-756, Korea.

Submitted May 24, 2014; Revised Jul. 24, 2014; Accepted Aug. 25, 2014
}

possible alternatives to antibiotics, as well as showing growth-promoting effects which are on par with antibiotics (Hernandez et al., 2004; Cross et al., 2007; Windisch et al., 2008). Many herbal products are already utilized in commercial applications. Oregano (Origanum vulgare L.) is one of the many herb extracts is used as an additive to poultry diets. Oregano is an aromatic plant, containing more than 30 mainly phenolic antioxidants constituents, with anti-microbial and anti-inflammatory activity (Alma et al., 2003). Oregano supplementation has been shown to have a beneficial effect on productivity, mortality, modulation of gastrointestinal microflola, pathogen inhibition, and immune system stimulation in poultry.

Although, modern strains of ducks have been intensively selected for growth and feed efficiency, modern ducks exhibit excessive body fat. Moreover, duck meat, characterized by a high proportion of unsaturated fat content, is particularly susceptible to oxidation causing rancidity and deterioration in flavor and color (Suryanti et al., 2014). That is one of the main problems encountered by 
both duck producers and consumers today, because it can cause great economic loss because of shortened storage life of meats. In order to improve the stability of meat-derived product, oregano must be considered an important candidate with well-known biological and antioxidant effects. Considering that, until now, there are few studies on ducks, the influence of dietary oregano on live performance, oxidative lipid stability, and on the quality of breast meat was investigated in ducks.

\section{MATERIAL AND METHODS}

\section{Extraction of samples}

For 1,1-diphenyl-2-picryl-hydrazyl (DPPH) radical scavenging activity, phenolic and flavonoid content in dried oregano powder (DOP), $40 \mathrm{~g}$ of dried sample were extracted with $400 \mathrm{~mL}$ of distilled water at $85^{\circ} \mathrm{C}$ in reflux for $3 \mathrm{~h}$ to obtain an initial extract (fraction I). The residues were extracted with $400 \mathrm{~mL}$ of distilled water at $85^{\circ} \mathrm{C}$ for 2 $\mathrm{h}$ to obtain fraction II. After cooling to room temperature and then filtering (Whatman No. 2 filter paper), the two fractions were combined and dried under vacuum below $40^{\circ} \mathrm{C}$. The extracts were completely dried in a freeze-drier and stored at $-20^{\circ} \mathrm{C}$ until further use.

\section{Measurement of total phenolic content}

Total phenolic contents of the extract were determined spectrophotometrically according to the Folin-Ciocalteu colorimetric method (Singleton and Rossi, 1965). A $150 \mathrm{~mL}$ of sample at a concentration of $1 \mathrm{mg} / \mathrm{mL}, 2.4 \mathrm{~L}$ of deionized water, and $150 \mathrm{~mL}$ of $0.25 \mathrm{~N}$ Folin-Ciocalteu reagents were combined in a plastic vial and then $300 \mathrm{~mL}$ of $1 \mathrm{~N} \mathrm{Na}_{2} \mathrm{CO}_{3}$ solution was added. The solution was incubated in a dark place for $2 \mathrm{~h}$ and the absorbance was measured at $725 \mathrm{~nm}$ using a spectrophotometer (Hewlett Packard 8452A, Diode Array, Santa Clara, CA, USA). Total phenolic content of the extract were expressed as microgram catechin equivalents (CE)/mg.

\section{Measurement of total flavonoids}

Total flavonoid content was determined by using the modified method described by Meda et al. (2005). In brief, $0.25 \mathrm{~mL}$ of sample $(1 \mathrm{mg} / \mathrm{mL})$ was added to a tube containing $1 \mathrm{~mL}$ of double-distilled water. Next, $0.075 \mathrm{~mL}$ of $5 \% \mathrm{NaNO}_{2}, 0.075 \mathrm{~mL}$ of $10 \% \mathrm{AlCl}_{3}$ and $0.5 \mathrm{~mL}$ of $1 \mathrm{M}$ $\mathrm{NaOH}$ were added sequentially. Finally, the volume of the reacting solution was adjusted to $2.5 \mathrm{~mL}$ with doubledistilled water. The absorbance of the solution at a wavelength of $410 \mathrm{~nm}$ was detected using the Ultrospec 2100 pro UV-visible spectrophotometer. Quercetin was used as standard to quantify the total flavonoid content of the extract. Results were expressed in microgram quercetin equivalents $(\mathrm{QE}) / \mathrm{mg}$.

Measurement of free radical scavenging activity on 1,1diphenyl-2-picryl-hydrazyl assay

The DPPH free radical scavenging activity of samples was determined according to the modified method of Brand-Williams et al. (1995). L-ascorbic acid and tocopherol were used as a positive control, and then diluted to obtain five different concentrations. A quantity of each sample $(10 \mu \mathrm{L})$ and standards were mixed with DPPH solution (100 $\mu \mathrm{L}, 0.2 \mathrm{mM}$ DPPH in dimethyl sulfoxide. The mixture was then incubated at $37^{\circ} \mathrm{C}$ for $30 \mathrm{~min}$. The absorbance was measured by a spectrophotometer (Ultrospec 2100 pro UV-visible spectrophotometer; Amersham Pharmacia Biotech Co., Piscataway, NJ, USA) at $517 \mathrm{~nm}$. The inhibition percentage was calculated from the following equation: Inhibition $\%=$ ([absorbance of control - absorbance of sample])/absorbance of control) $\times 100$.

\section{Preparation of oregano powder}

For feeding the ducks, Oregano (Origanum vulgare L.), which was cultivated in Korea, was obtained from Namwon Herb Food Cluster Business Association (Namwon, Korea). Leaves and stems were air dried at room temperature in the shade for a month, and then were powdered with a mill (IKA M 20, IKA, Staufen, Germany). The powdered oregano was stored at $4{ }^{\circ} \mathrm{C}$ until further use.

\section{Experimental design}

All animal managements and experimental procedures were approved by the University Institutional Animal Care and Use Committee.

A feeding study with 165 one-day-old Cherry Valley meat-strain ducks (body weight $288 \pm 0.5 \mathrm{~g}$ ) was conducted in floor fens for 42 days. The ducks were individually weighed and were assigned to 5 treatments (33 ducks/treatment) with 3 replicates (11 ducks/pen) each based on body weights. Environmental temperature was gradually reduced from $35^{\circ} \mathrm{C}$ on day 1 , to $22^{\circ} \mathrm{C}$ until the end of experiment and $24 \mathrm{~h}$ consistent light was provided. During the entire trial, the experimental diets and fresh water were offered ad libitum daily. The experimental diet was typically of corn-soybean meal, and the feeding program consisted of two phases. During the first $21 \mathrm{~d}$, ducks were fed the crumble starter diet [metabolizable energy (ME), 2,950 kcal/kg; crude protein (CP), 20\%] and fed a finisher diet from 22 to $42 \mathrm{~d}$ (ME, 3,100 kcal/kg; (CP), $17 \%$ ) pelleted with a $4-\mathrm{mm}$ die. The calculated nutrient concentrations of the experimental diet and analyzed nutrients concentrations of oregano are listed in Table 1 and 2 , respectively. Dietary treatments in the experiment 
Table 1. Calculated chemical composition of experimental diet (as-fed basis)

\begin{tabular}{lcc}
\hline & Starter $^{1}$ & Finisher \\
\hline Calculated composition & & \\
ME (kcal/kg) & 2,950 & 3,100 \\
CP (\%) & 20.0 & 17.0 \\
Methionine (\%) & 0.40 & 0.30 \\
Lysine (\%) & 0.90 & 0.65 \\
Ca (\%) & 0.8 & 0.8 \\
Total P (\%) & 1.0 & 1.0 \\
Crude fat (\%) & 2.5 & 2.5 \\
Crude fiber (\%) & 5.5 & 5.5 \\
Ash (\%) & 8.0 & 8.0 \\
\hline
\end{tabular}

ME, metabolizable energy; $\mathrm{CP}$, crude protein.

${ }^{1}$ Stater diet (Crumble) provided during d 1 to 21 ; finisher diet (pellet) provided during $\mathrm{d} 22$ to 42 .

included an unsupplemented diet (CON; no antibiotic, no DOP), a diet supplemented with $0.1 \%$ Patrol (ANT; antibiotic), and 3 DOP treatment groups, with varying amounts of DOP. The DOP treatment groups consisted of $0.1 \%$ DOP, $0.5 \%$ DOP, and $1.0 \%$ DOP-fed groups, respectively.

\section{Chemical composition of dried oregano powder}

Moisture, crude protein, crude fat, crude ash, and crude fiber contents of DOP were determined according to AOAC (1995) methods. Calcium, phosphorus, and iron contents were determined by inductively coupled plasma (ICP)atomic emission spectroscopy (ICPS-7510, Shimadzu, Japan). Gross energy was measured using a bomb calorimeter (PARR 1351, USA).

\section{Growth performance and sampling}

Body weight and feed intake per pen were recorded at the end of the experiment ( $\mathrm{d} 42$ ), and feed conversion ratio was calculated. At the end of the feeding period, blood samples of 9 ducks from each treatment ( 3 ducks/pen) were randomly collected from the wing vein, and breast meat samples of same ducks were also taken to determine the activities of 2 antioxidant enzymes, superoxide dismutase (SOD) and glutathione peroxidase (GPx). Blood samples

Table 2. Chemical composition of dried oregano powder

\begin{tabular}{lc}
\hline Chemical composition & Dried oregano powder \\
\hline Moisture $(\%)$ & $10.5 \pm 0.28$ \\
Gross energy $(\mathrm{kcal} / \mathrm{kg})$ & $4,192 \pm 62.23$ \\
Crude protein $(\%)$ & $15.2 \pm 0.42$ \\
Crude fat $(\%)$ & $2.0 \pm 0.14$ \\
Crude fiber $(\%)$ & $14.4 \pm 0.42$ \\
$\mathrm{Ca}(\mathrm{mg} / \mathrm{kg})$ & $8,028 \pm 69.30$ \\
$\mathrm{P}(\mathrm{mg} / \mathrm{kg})$ & $2,772 \pm 11.31$ \\
$\mathrm{Fe}(\mathrm{mg} / \mathrm{kg})$ & $113.3 \pm 4.53$ \\
\hline
\end{tabular}

Values are represented as mean \pm standard deviation $(n=3)$. for enzyme determinations were placed in serum separator tubes (BD Vacutainer) and were centrifuged at 3,000 rpm for $15 \mathrm{~min}$. The serum was stored at $-20^{\circ} \mathrm{C}$ until used. Breast muscles were washed in phosphate buffer, $\mathrm{pH}$ 7.4. Then, the tissue $(400 \mathrm{mg}$ ) was homogenized in $1 \mathrm{~mL} / \mathrm{gm}$ cold phosphate-buffered saline (PBS)/ ethylenediaminetetraacetic acid (EDTA) buffer (PBS, 100 mg EDTA, pH 7.4). The homogenate was centrifuged at $10,000 \mathrm{rpm}$ for $15 \mathrm{~min}$ at $4^{\circ} \mathrm{C}$. The supernatant was used for the estimation of antioxidant enzymes.

\section{Superoxide dismutase, glutathione peroxidase, and protein assay}

The activities of SOD and GPx in breast muscle and serum were measured using a commercial kit from Enzo Life Sciences Company (Ann Arbor MI, USA) according to the instructions of the manufacturer. The protein concentrations in breast muscle were quantitated by the bicinchonibate (BCA) method, using a protein assay kit (Bio-Rad, Hercules, CA, USA).

\section{Physicochemical properties of raw duck breast meat}

At the end of the experiment, 9 ducks (3 ducks/pen) of similar body weight from each group were killed, and breast meat samples of each individual duck was taken, after completion of bleeding from the jugular vein. The physiochemical qualities of the breast meat were analyzed. The $\mathrm{pH}$ values of raw breast meat were measured $24 \mathrm{~h}$ postslaughter, using a digital $\mathrm{pH}$ meter (8603, Metrohm, Swiss) after blending $10 \mathrm{~g}$ of finely homogenized sample $(3 \mathrm{~mm})$ with $90 \mathrm{~mL}$ of double-distilled water. For cooking loss estimation, raw meat samples $(3 \times 5 \times 8 \mathrm{~cm})$ were placed inside plastic bag after weighing and were then cooked in a water bath at $80^{\circ} \mathrm{C}$ for $1 \mathrm{~h}$. The samples were cooled at $4^{\circ} \mathrm{C}$ temperature for $2 \mathrm{~h}$ and weighed again. Cooking losses were calculated based on the difference in weight between the initial raw and cooked samples. The shear force of breast meats was estimated with an Instron 3343 (US/MX50, A\&D Co., Norwood, MA, USA) attached to a Warner Bratzler shearing device. Cores $(2 \times 2 \times 1 \mathrm{~cm})$ of each meat were analyzed at room temperature with a crosshead speed of $100 \mathrm{~mm} / \mathrm{min}$. The average shear force value was calculated for each treatment and was expressed as $\mathrm{kg} / \mathrm{cm}^{2}$. For measurement of 2-thiobarbituric acid reactive substances (TBARS), breast meats were sliced in $1.5 \mathrm{~cm}$ thickness, and packed in a polyethylene tray covered with low-density polyethylene film. The amount of TBARS was measured by the modified method of Buege and Aust (1978). Five grams of sample was homogenized with $15 \mathrm{~mL}$ of distilled water using a homogenizer (IKA model T-25 Basic, Selangor, Malaysia) for $10 \mathrm{~s}$, after which $2 \mathrm{~mL}$ of homogenate was placed in a test tube, and $2 \mathrm{~mL}$ of the thiobarbituric acid (TBA)/trichloroacetic acid (TCA) 
Table 3. Total phenolic and flavonoid content in water extracts of oregano

\begin{tabular}{lc}
\hline Oregano extract & Contents \\
\hline Total phenolic content & $21.29 \pm 0.84$ \\
$(\mu \mathrm{g}$ CE/mg extract $)$ & \\
Total flavonoid content & $730.36 \pm 2.35$ \\
$(\mu \mathrm{g} Q \mathrm{Q} / \mathrm{mg}$ extract $)$ & \\
\hline
\end{tabular}

$\mathrm{CE}$, catechin equivalents; $\mathrm{QE}$, quercetin equivalents.

Values are represented as mean \pm standard deviation $(n=6)$.

reagent $(0.72 \%$ TBA, $37.5 \%$ TCA) was added and mixed with the homogenate. The mixture was then incubated in a $95^{\circ} \mathrm{C}$ water bath for $15 \mathrm{~min}$, and then centrifuged for 10 $\min$ at 3,000 rpm. The absorbance values of the each solution and reagent blank were measured at $531 \mathrm{~nm}$. The TBARS of the samples were determined at 1,5 , and 10 days of storage $\left(4^{\circ} \mathrm{C}\right)$, respectively.

\section{Statistical analysis}

The pen was the experimental unit for growth performance; whereas, each duck was the experimental unit for antioxidant enzyme activity, and physicochemical properties. Data were statistically analyzed using the general linear model procedure of the SAS program (SAS, 2002). Tukey's test was performed to detect the significance of differences among groups, and the difference of TBARS values was determined every storage days. The statistical difference of the values was expressed at $\mathrm{p}<0.05$ and results are expressed as means \pm standard error of the mean.

\section{RESULT}

The DOP contained around $4,192 \pm 62.23 \mathrm{kcal} / \mathrm{kg}$ of gross energy. Moisture, crude protein, crude fat, crude fiber, $\mathrm{Ca}, \mathrm{P}$, and $\mathrm{Fe}$ contents in DOP were $10.5 \pm 0.28 \%$, $15.2 \pm 0.42 \%, 2.0 \pm 0.14 \%, 14.4 \pm 0.42 \%, 8,028 \pm 69.30 \mathrm{mg} / \mathrm{kg}$, $2,772 \pm 11.31 \mathrm{mg} / \mathrm{kg}$ and $113.3 \pm 4.53 \mathrm{mg} / \mathrm{kg}$, respectively (Table 2).

The total phenolic and flavonoids contents of the oregano extract were determined as $21.29 \pm 0.84 \mu \mathrm{g} \mathrm{CE} / \mathrm{mg}$ and 730.06 $\pm 2.35 \mu \mathrm{g}$ QE/mg extract, respectively (Table 3).

The DPPH radical scavenging activity of oregano
Table 4. DPPH radical scavenging activities (\%) of dried oregano extracts

\begin{tabular}{lrrc}
\hline $\begin{array}{c}\text { Concentration } \\
(\mu \mathrm{g} / \mathrm{mL})\end{array}$ & Oregano & Ascorbic acid & Tocopherol \\
\hline 10 & $6.65 \pm 0.52$ & $94.61 \pm 1.21$ & - \\
50 & $5.52 \pm 0.88$ & $95.19 \pm 1.04$ & - \\
100 & $9.52 \pm 0.97$ & $95.21 \pm 0.89$ & - \\
500 & $17.21 \pm 1.58$ & $94.80 \pm 1.08$ & $2.86 \pm 0.15$ \\
1,000 & $28.68 \pm 2.32$ & $95.27 \pm 1.57$ & $17.19 \pm 0.44$ \\
\hline
\end{tabular}

DPPH, 1,1-diphenyl-2-picryl-hydrazyl.

Values are represented as mean \pm standard deviation $(n=6)$

extract at the concentration of $1,000 \mu \mathrm{g} / \mathrm{mL}$ was $28.68 \pm 2.32 \%$, which was lower than that of ascorbic acid $(95.27 \pm 1.57 \%)$, but was higher than that of tocopherol (17.19 \pm 0.44$)$ (Table 4).

Ducks fed diets supplemented with DOP for 42 days showed no significant difference in weight gain, feed intake, and feed conversion compared with the control groups (Table 5).

As shown in Table 6, ducks fed with $0.5 \%$ and $1 \%$ DOP showed higher GPx activity in breast tissue than that of ANT treatment. In addition, the addition of $0.5 \%$ and $1 \%$ DOP increased the serum SOD activity compared with CON and ANT treatments.

The $\mathrm{pH}$ and shear force values were not different among treatments, but cooking loss was lower in ducks fed with DOP diets compared to ducks fed with control diets. Furthermore, the TBARS values at $5 \mathrm{~d}$ post slaughter were found to be decreased in $0.5 \%$ and $1 \%$ DOP treatments compared with control groups (Table 7).

\section{DISCUSSION}

Herb plants are rich source of a many biologically active substances and medicinal components (Park et al., 2014). Among these substances, phenolic acids and flavonoids particularly, have been shown to have various physiological and biochemical functions in the body. We confirmed that oregano also contained total phenolic and flavonoid concentration of $21.39 \mu \mathrm{g} \mathrm{CE} / \mathrm{mg}$ extract and $730.36 \mu \mathrm{g} \mathrm{QE} / \mathrm{mg}$ extract (Table 2). Phenolic compounds,

Table 5. Effect of dietary dried oregano powder (DOP) supplementation on growth performance in meat ducks ${ }^{1}$

\begin{tabular}{lccccccc}
\hline Treatment & $\mathrm{CON}^{2}$ & $\mathrm{ANT}^{2}$ & $0.1 \% \mathrm{DOP}^{2}$ & $0.5 \% \mathrm{DOP}^{2}$ & $1 \% \mathrm{DOP}^{2}$ & SEM & p-value \\
\hline Initial BW (g) & 285 & 287 & 288 & 289 & 290 & 2.92 & 0.987 \\
Final BW (g) & 2,994 & 3,084 & 2,973 & 3,032 & 2,964 & 26.71 & 0.585 \\
Weight gain (g) & 2,715 & 2,796 & 2,682 & 2,746 & 2,678 & 26.92 & 0.597 \\
Feed intake (g) & 7,558 & 7,422 & 7,200 & 7,071 & 6,644 & 164.0 & 0.497 \\
Feed conversion ratio & 2.79 & 2.66 & 2.71 & 2.59 & 2.54 & 0.07 & 0.881 \\
\hline
\end{tabular}

BW, body weight; SEM, standard error of means.

${ }^{1}$ Each mean was calculated 3 pens per treatment $(\mathrm{n}=3)$.

${ }^{2} \mathrm{CON}$, basal diet (no antibiotic, no dried oregano powder); ANT, CON+0.1\% antibiotic (Patrol) diet; $0.1 \% \mathrm{DOP}, \mathrm{CON}+0.1 \%$ dried oregano powder; $0.5 \%$ $\mathrm{DOP}, \mathrm{CON}+0.5 \%$ dried oregano powder; $0.1 \% \mathrm{DOP}, \mathrm{CON}+1 \%$ dried oregano powder. 
Table 6. Effect of dietary dried oregano powder (DOP) supplementation on superoxide dismutase (SOD) and glutathione peroxidase (GPx) in meat ducks ${ }^{1}$

\begin{tabular}{|c|c|c|c|c|c|c|c|}
\hline Treatment & $\mathrm{CON}^{2}$ & $\mathrm{ANT}^{2}$ & $0.1 \% \mathrm{DOP}^{2}$ & $0.5 \% \mathrm{DOP}^{2}$ & $1 \% \mathrm{DOP}^{2}$ & SEM & p-value \\
\hline \multicolumn{8}{|l|}{$\overline{G P x}$} \\
\hline Tissue (U/mg of protein) & $1.47^{\mathrm{ab}}$ & $1.28^{\mathrm{b}}$ & $1.46^{\mathrm{ab}}$ & $1.62^{\mathrm{a}}$ & $1.74^{\mathrm{a}}$ & 0.05 & 0.022 \\
\hline Serum $(\mathrm{U} / \mathrm{mL})$ & 6.26 & 7.16 & 6.51 & 7.68 & 7.51 & 0.28 & 0.451 \\
\hline \multicolumn{8}{|l|}{ SOD } \\
\hline Tissue $\left(10^{3} \mathrm{U} / \mathrm{mg}\right.$ of protein $)$ & 7.13 & 7.19 & 13.05 & 6.97 & 11.94 & 1.01 & 0.202 \\
\hline Serum $\left(10^{8} \mathrm{U} / \mathrm{mL}\right)$ & $1.27^{\mathrm{b}}$ & $1.38^{\mathrm{b}}$ & $2.68^{\mathrm{b}}$ & $3.84^{\mathrm{a}}$ & $3.52^{\mathrm{a}}$ & 0.26 & 0.001 \\
\hline
\end{tabular}

SEM, standard error of means.

${ }^{1}$ Each mean represented by 9 ducks per treatment $(n=9)$.

${ }^{2} \mathrm{CON}$, basal diet (no antibiotic, no dried oregano powder); ANT, CON+0.1\% antibiotic (Patrol) diet; $0.1 \% \mathrm{DOP}, \mathrm{CON}+0.1 \%$ dried oregano powder; $0.5 \%$ DOP, $\mathrm{CON}+0.5 \%$ dried oregano powder; $0.1 \% \mathrm{DOP}, \mathrm{CON}+1 \%$ dried oregano powder.

including flavonoids, are important plant constituents because the phenolic content of plants may relate directly to the antioxidant activities (Kahkonen et al., 1999) and herb extracts have confirmed to possess a high linear relationship between the phenol concentration and antioxidant activity (Zheng and Wang, 2001; Cai et al., 2004; Kim et al., 2011). The DPPH radical scavenging activity assay is one of the most widely used method for rapid screening the antioxidant activity of plant extract. Sokmen et al. (2004) reported that DPPH radical scavenging activity of oregano extracts are on par with those of antioxidant butylated hydroxytoluene. In our study, oregano extracted exhibits more potent DPPH radical scavenging activities than tocopherol, though the values were less than that of ascorbic acid. Therefore, we hypothesize that the supplementation of DOP into duck diets would result in positive effects in growth performance, antioxidant enzyme activity, and physicochemical properties of the breast meat of meat ducks.

However, in our in vivo study, the growth performance of ducks fed the DOP did not reveal a significant difference, and previous reports investigating the effect of oregano on the performance parameters are inconsistent among researchers (Lewis et al., 2003; Hernandez et al., 2004; Bampidis et al., 2005; Cross et al., 2007). Despite the existence of some phytochemicals as growth promoters in herb plant, several authors reported no positive effects on performance parameters in poultry (Lewis et al., 2003; Cross et al., 2007). On the other hand, several authors found that herbs and essential oil extracted from herbs did exhibit significant effects on the performance of poultry (Hernandez et al., 2004; Bampidis et al., 2005). These contradictory results can be explained because healthy and well nourished birds reared in clean, ideal environmental condition, often may not respond to growth promoting supplements. This was confirmed by broilers that were challenged with coccidiosis which showed improved growth performance while being fed herb extracts (Arczewska-Wlosek and Swiatkiewicz, 2013). In the present study, the ducks were raised in clean condition; growth promoting agents such as oregano might have more effect when animals are housed under poor environmental or infectious conditions.

Antioxidant enzymes such as SOD and GPx are the first line defense antioxidants (Ray and Husain, 2002). In the present study, an increase in these GPx and SOD enzymes were observed in DOP treatments. Changes in these enzymes could be attributed to the presence of phenolic compounds, rich in terpenoids, such as carvacrol, thymol, and rosmarinic acid, in the oregano plant (Shan et al., 2005). The substances have strong antioxidant properties, which could protect organisms against oxidative stress. In the present study, similar to the in vitro DPPH radical scavenging activity of oregano extract, in vivo study

Table 7. Effect of dietary dried oregano powder (DOP) supplementation on meat quality in meat ducks ${ }^{1}$

\begin{tabular}{lccccccc}
\hline Treatment & $\mathrm{CON}^{2}$ & $\mathrm{ANT}^{2}$ & $0.1 \% \mathrm{DOP}^{2}$ & $0.5 \% \mathrm{DOP}^{2}$ & $1 \% \mathrm{DOP}^{2}$ & SEM & $\mathrm{p}$-value \\
\hline $\mathrm{pH}$ & 5.96 & 5.90 & 5.92 & 5.95 & 5.96 & 0.01 & 0.309 \\
Cooking loss $(\%)$ & $15.17^{\mathrm{a}}$ & $9.79^{\mathrm{b}}$ & $7.71^{\mathrm{b}}$ & $7.76^{\mathrm{b}}$ & $8.35^{\mathrm{b}}$ & 0.57 & 0.001 \\
Shear force $\left(\mathrm{kg} / \mathrm{cm}^{2}\right)$ & 2.82 & 2.79 & 2.37 & 2.54 & 2.60 & 0.05 & 0.063 \\
TBARS $(\mathrm{mg} / \mathrm{kg})$ & & & & & & \\
$\quad 1 \mathrm{~d}$ & 0.12 & 0.12 & 0.13 & 0.11 & 0.11 & 0.01 & 0.479 \\
$5 \mathrm{~d}$ & $0.29^{\mathrm{a}}$ & $0.29^{\mathrm{ab}}$ & $0.29^{\mathrm{ab}}$ & $0.27^{\mathrm{b}}$ & $0.22^{\mathrm{b}}$ & 0.01 & 0.025 \\
$10 \mathrm{~d}$ & 0.31 & 0.23 & 0.24 & 0.14 & 0.20 & 0.02 & 0.224 \\
\hline
\end{tabular}

SEM, standard error of means; TBARS, thiobarbituric acid reactive substance.

${ }^{1}$ Each mean represented by 9 ducks per treatment $(\mathrm{n}=9)$.

${ }^{2} \mathrm{CON}$, basal diet (no antibiotic, no dried oregano powder); ANT, CON+0.1\% antibiotic (Patrol) diet; $0.1 \% \mathrm{DOP}, \mathrm{CON}+0.1 \%$ dried oregano powder; $0.5 \%$ DOP, $\mathrm{CON}+0.5 \%$ dried oregano powder; $0.1 \% \mathrm{DOP}, \mathrm{CON}+1 \%$ dried oregano powder. 
showed that DOP also possess a significant radical scavenging activity and have a potent antioxidant capacity. The finding of the present study is in agreement with those of other studies (Song et al., 2010; Yao et al., 2010), which have reported a significant relationship between phenolic content and antioxidant enzyme activity. Therefore, the higher concentrations of SOD and GPx, due to the addition of DOP, may provide a more efficient scavenging of free reactive radicals in ducks.

Cooking loss is known to be one of a main factor affecting meat quality, because some nutrients may be lost in the exudates by water loss, and affect juiciness and tenderness. In our study, the decrease in the cooking loss of breast meat of ducks fed with the DOP was statistically significant, though the detailed reasons for this are unknown. Therefore, further study is needed, to determine the systemic estimation of the association between DOP and the meat quality of ducks. However, Symeon et al. (2009) reported that dietary supplementation of oregano essential oil decreased the cooking loss of broilers, and Kołodziej-Skalska et al. (2011) reported that dietary plant extracts mixture $(5.4 \% \quad(\mathrm{wt} / \mathrm{wt})$ Origanum spp. $+3.2 \%$ Cinnamomum spp. $+2.2 \%$ Capsicum annum) decreased the cooking loss and increased the water holding capacity of pork. The findings of our study support these studies, which determined that plant extract could affect meat quality by decreasing the cooking loss of meats.

Some plant extracts including oregano have been shown to inhibit peroxidation of polyunsaturated fatty acids (Bhale et al., 2007). Furthermore, Helichrysum italicum (curry plant) extract was found to inhibit or delay the formation of oxygen free radicals, particularly superoxide ions and hydroxyl radical (Facino et al., 1990). Loperz-Bote et al. (1998) also suggested that the breast meat of broilers fed diets containing herbal extracts had lower concentrations of lipid oxidation products than those of the control group. Jang et al. (2008) found that broiler muscles fed plant extract showed higher total phenolic content than those fed the control diet, and that the DPPH radical scavenging ability of muscle was greater and that TBARS value were decreased in the treatment groups. The present study also observed that the DOP addition decreased the breast meat TBARS level of ducks relative to that of the control. The results from the present study show that DOP has the potential to inhibit the production of lipids in ducks thereby improving the storage stability of the meat after slaughter. Similarly, oregano has been shown to improve the duration of meat storage after slaughter in poultry (Botsoglou et al., 2003). Therefore, we believe that antioxidant substances in DOP are delivered to the muscle of ducks, and, the antioxidant defense system counteracts the action of prooxidants.

In conclusion, the present study shows that DOP is a valuable natural feed ingredient for meat ducks, particularly in terms of greater SOD and GPx enzyme activities, lower meat cooking loss, and lower TBARS values.

\section{ACKNOWLEDGMENTS}

This paper was supported by research funds of Chonbuk National University in 2011 and Namwon Herb Feed Cluster Business Association.

\section{REFERENCES}

Alma, M. H., A. Mavi, A. Yildirim, M. Digrak, and T. Hirata. 2003. Screening chemical composition and in vitro antioxidant and antimicrobial activities of the essential oils from Origanum syriacum L. growing in turkey. Biol. Pharm. Bull. 26:17251729.

AOAC. 1995. Official Method of Analysis. 16th ed. Association of Official Analytical Chemists, Washington, DC, USA.

Arczewska-Wlosek, A. and S. Swiatkiewicz. 2013. Improved performance due to dietary supplementation with selected herbal extracts of broiler chickens infected with Eimeria spp.. J. Anim. Feed Sci. 22:257-263.

Bampidis, V. A., V. Christodoulou, P. Florou-Paneri, E. Christaki, P. S. Chatzopoulou, T. Tsiligianni, and A. B. Spais. 2005. Effect of dietary dried oregano leaves on growth performance, carcass characteristics and serum cholesterol of female early maturing turkeys. Br. Poult. Sci. 46:595-601.

Bhale, S. D., Z. Xu, W. Prinyawiwatkul, J. M. King, and J. S. Godber. 2007. Oregano and rosemary extracts inhibit oxidation of long-chain n-3 fatty acids in menhaden oil. J. Food Sci. 72:504-508.

Botsoglou, N. A., S. H. Grigoropoulou, E. Botsoglou, A. Govaris, and G. Papageorgiou. 2003. The effects of dietary oregano essential oil and [alpha]-tocopheryl acetate on lipid oxidation in raw and cooked turkey during refrigerated storage. Meat Sci. 65:1193-1200.

Brand-Williams, W., M. E. Cuvelier, and C. Berset. 1995. Use of a free radical method to evaluate antioxidant activity. LWT-Food Sci. Technol. 28:25-30.

Cai, Y., Q. Luo, M. Sun, and H. Corke. 2004. Antioxidant activity and phenolic compounds of 112 traditional Chinese medicinal plants associated with anticancer. Life Sci. 74:2157-2184.

Cross, D. E., T. Acamovic, S. G. Deans, and R. M. McDevitt. 2002. The effect of dietary inclusion of herbs and their volatile oils on the performance of growing chickens. Br. Poult. Sci. 43:3335.

Cross, D. E., R. M. McDevitt, K. Hillman, and T. Acamovic. 2007. The effect of herbs and their associated essential oils on performance, dietary digestibility and gut microflora in chickens from 7 to 28 days of age. Br. Poult. Sci. 48:496-506.

Facino, R. M., M. Carini, L. Franzoi, O. Pirola, and E. Bosisio. 1990. Phytochemical characterization and radical scanvenger activity of flavonoids from Helichrysum italicum G. Don (Compositae). Pharmacol. Res. 22:709-721.

Guo, F. C., B. A. Williams, R. P. Kwakkel, H. S. Li, X. P. Li, J. Y. Luo, W. K. Li, and M. W. A. Verstegen. 2004. Effects of 
mushroom and herb polysaccharides, as alternatives for antibiotics, on the cecal microbial ecosystem in broiler chickens. Poult. Sci. 83:175-182.

Hernandez, F., J. Madrid, V. Garcia, J. Orengo, and M. D. Megias. 2004. Influence of two plant extracts on broilers performance, digestibility, and digestive organ size. Poult. Sci. 83:169-174.

Jang, A., X. D. Liu, M. H. Shin, B. D. Lee, S. K. Lee, J. H. Lee, and C. Jo. 2008. Antioxidative potential of raw breast meat from broiler chicks fed a dietary medicinal herb extract mix. Poult. Sci. 87:2382-2389.

Kahkonen, M. P, A. I. Hopia, H. J. Vuorela, J. P. Rauha, K. Pihlaja, T. S. Kujala, and M. Heinonen. 1999. Antioxidant activity of plant extracts containing phenolic compounds. J. Agric. Food Chem. 47:3954-3962.

Kim, I. S., M. R. Yang, O. H. Lee, and S. N. Kang. 2011. Antioxidant activities of hot water extracts from various spices. Int. J. Mol. Sci. 12:4120-4131.

Kołodziej-Skalska, A., A. Rybarczyk, B. Matysiak, E. Jacyno, A. Pietruszka, and M. Kawęcka. 2011. Effect of dietary plant extracts mixture on pork meat quality. Acta Agric. Scand. Sect. A, Anim. Sci. 6:80-85.

Lewis, M. R., S. P. Rose, A. M. Mackenzie, and L. A. Tucker. 2003. Effects of dietary inclusion of plant extracts on the growth performance of male broiler chickens. Br. Poult. Sci. 44:S43-S44.

Lopez-Bote, C. J., J. I. Gray, E. A. Gomaa, and C. J. Flegal. 1998. Effect of dietary administration of oil extracts from rosemary and sage on lipid oxidation in broiler meat. Br. Poult. Sci. 39:235-240.

Meda, A., C. E. Lamien, M. Romito, J. Millogo, and O. G. Nacoulma. 2005. Determination of the total phenolic, flavonoid and proline contents in Burkina Fasan honey, as well as their radical scavenging activity. Food Chem. 91:571-577.

Park, J. H., S. N. Kang, G. M. Chu, and S. K. Jin. 2014. Growth performance, blood cell profiles, and meat quality properties of broilers fed with Saposhnikovia divaricata, Lonicera japonica, and Chelidonium majus extracts. Livest. Sci. 165:87-94.
Ray, G. and S. A. Husain. 2002. Oxidants, antioxidants and carcinogenesis. Indian J. Exp. Biol. 40:1213-1232.

SAS. 2002. SAS User's Guide: Statistics, Version 9.0. SAS Inst. Inc., Cary, NC, USA.

Shan, B., Y. Z. Cai, M. Sun, and H. Corke. 2005. Antioxidant capacity of 26 spice extracts and characterization of their phenolic constituents. J. Agric. Food Chem. 53:7749-7759.

Singleton, V. L. and J. A. Rossi, Jr. 1965. Colorimetry of total phenolics with phosphomolybdic-phosphotungstic acid reagents. Am. J. Enol. Vitic. 16:144-158.

Sokmen, M., J. Serkedjieva, D. Dafarera, M. Gulluce, M. Polissiou, B. Tepe, H. A. Akpulat, F. Sahin, and A. Sokmen. 2004. In vitro antioxidant, antimicrobial, and antiviral activities of the essential oil and various extracts from herbal parts and callus cultures of Origanum acutidens. J. Agric. Food Chem. 52:3309-3312.

Song, F. L., R. Y. Gan, Y. Zhang, Q. Xiao, L. Kuang, and H. B. Li. 2010. Total phenolic contents and antioxidant capacities of selected Chinese medicinal plants. Int. J. Mol. Sci. 11:23622372.

Suryanti, U., V. P. Bintoro, U. Atmomarsono, Y. B. Pramono, and A. M. Legowo. 2014. Antioxidant activity of Indonesian endogenous duck meat marinated in ginger (Zingiber officinale Roscoe) extract. Int. J. Poult. Sci. 13:102-107.

Symeon, G. K., C. Zintilas, A. Ayoutanti, J. A. Bizelis, and S, G. Deligeorgis. 2009. Effect of dietary oregano essential oil supplementation for an extensive fattening period on growth performance and breast meat quality of female mediumgrowing broilers. Can. J. Anim. Sci. 89:331-334.

Windisch, W., K. Schedle, C. Plitzner, and A. Kroismayer. 2008. Use of phytogenetic products as feed additives for swine and poultry. J. Anim. Sci. 86:140-148.

Yao, Y., W. Sang, M. Zhou, and G. Ren. 2010. Phenolic composition and antioxidant activities of 11 celery cultivars. J. Food Sci. 75:C9-C13.

Zheng, W. and S. Y. Wang. 2001. Antioxidant activity and phenolic compounds in selected herbs. J. Agric. Food Chem. 49:51665170 . 